\title{
KECENDERUNGAN TOPIK DAN JENIS PENELITIAN MAHASISWA PROGRAM STUDI PENDIDIKAN BAHASA MANDARIN UNIVERSITAS NEGERI SURABAYA
}

\author{
Maria Mintowati ${ }^{1}$, Tengsoe Tjahjono ${ }^{2}$, Hans Yosef Tandra Dasion ${ }^{3}$, \\ Pendidikan Bahasa Mandarin \\ Universitas Negeri Surabaya \\ Email: mintowati@unesa.ac.id ${ }^{1}$, tengsoetjahjono@unesa.ac.id ${ }^{2}$, hansdasion@unesa.ac.id ${ }^{3}$
}

\begin{abstract}
Abstrak
Penelitian berjudul "Kecenderungan Topik dan Jenis Penelitian Mahasiswa Angkatan 2010-2014 Program Studi Pendidikan Bahasa Mandarin Universitas Negeri Surabaya" bertujuan mendeskripsikan (1) topik penelitian; (2) jenis penelitian; (3) kecenderungan topik dan jenis penelitian mahasiswa angkatan 2010-2014 Prodi S-1 PBM Unesa. Sumber data berupa 236 skripsi. Data penelitian berupa topik dan jenis penelitian. Penelitian ini merupakan penelitian deskriptifkualitatif. Data dikumpulkan dengan teknik dokumentasi dan catat, kemudian dianalisis dengan teknik deskriptif dan persentase. Hasil penelitian ini adalah (1) topik-topik yang diteliti oleh mahasiswa angkatan 2010, 2011, 2012, 2013, dan 2014 adalah (a) pendidikan, (b) kebahasaan, dan (c) kesastraan. Topik pendidikan meliputi (a) penggunaan media dalam pembelajaran bahasa Mandarin, (b) penggunaan metode dalam pembelajaran bahasa Mandarin, (c) pengembangan bahan ajar. Topik kebahasaan mencakup (a) kesalahan berbahasa, (b) pragmatik, (c) sosiolinguistik, (d) keterampilan berbahasa. Topik kesastraan meliputi (a) stilistika, (b) psikologi sastra, dan (c) apresiasi karya sastra. (2) Jenis-jenis penelitian yang dipilih dan digunakan meliputi penelitian pendidikan dan penelitian non-pendidikan. Penelitian pendidikan meliputi (a) penelitian eksperimen, (b) penelitian dan pengembangan, dan (c) penelitian korelasi. Adapun penelitian non-pendidikan yang dipilih dan digunakan adalah penelitian deskriptif-kualitatif, baik untuk penelitian di bidang kebahasaan maupun kesastraaan. (3) Kecenderungan pemilihan topik dan jenis penelitian berjalan seiring. Dalam hal ini, pilihan topik pembelajaran bahasa Mandarin didominasi oleh penggunaan media dan metode pembelajaran bahasa Mandarin dan jenis penelitian yang digunakan adalah penelitian eksperimen. Berikutnya, topik kebahasaan yang banyak diteliti adalah penelitian kesalahan berbahasa Mandarin dan pragmatik, sedangkan topik penelitian tentang kesastraan yang banyak dipilh adalah stilistika dan psikologi sastra. Pilihan kedua topik tersebut sejalan dengan jenis penelitian yang mendominasi untuk digunakan yaitu penelitian deskriptif-kualitatif.
\end{abstract}

Kata kunci: kecenderungan, topik, jenis, penelitian

\section{A. PENDAhuluan}

Program studi Pendidikan Bahasa Mandarin Universitas Negeri Surabaya (Prodi PBM Unesa) telah menerima mahasiswa baru sejak 2010. Dalam perkembangannya, mahasiswa yang telah diluluskan hingga 2019 sebanyak 236 mahasiswa. Sebanyak 236 mahasiswa tersebut berasal dari angkatan 2010, 2011, 2012, 2013, dan 2014.

Sebagaimana dituangkan dalam Permenristekdikti nomor 44 tahun 2015 tentang standar Nasional Perguruan Tinggi (SNPT), utamanya dalam Bagian II Standar Hasil Penelitian pasal 44 ayat (4) dituliskan, "Hasil penelitian mahasiswa harus memenuhi ketentuan sebagaimana dimaksud pada ayat (2); capaian pembelajaran lulusan, dan ketentuan peraturan di perguruan tinggi." Dalam ayat (2) dinyatakan, "Hasil penelitian di perguruan tinggi diarahkan dalam rangka mengembangkan ilmu pengetahuan dan teknologi serta meningkatkan kesejahteraan masyarakat dan daya saing bangsa." 
Pernyataan tersebut menarik untuk dikonfirmasikan ke hasil penelitian mahasiswa Prodi PBM Unesa yang telah menyelesaikan studinya, khususnya pada penelitian yang telah mereka kerjakan sebagai salah satu syarat kelulusan dari Prodi S-1 untuk meraih gelar sarjana pendidikan (S.Pd.)

Berdasarkan pengamatan yang dilakukan, terdapat keragaman topik dan jenis penelitian yang telah dihasilkan oleh para mahasiswa Prodi PBM Unesa mulai dari angkatan 20102014. Berdasarkan topik, ada penelitian bertopikkan pendidikan dan pembelaharan bahasa Mandarin (BM), tetapi ada pula penelitian bertopikkan non-pendidikan. Lebih lanjut, kecenderungan jenis penelitian yang dilakukan juga beragam, misalnya penelitian deksriptif, korelasi,eksperimen, penelitian dan pengembangan, dan sebagainya. Selain itu, ada juga penelitian sastra, penelitian bahasa, dan lain-lain.

Berdasarkan hal-hal yang telah disampaikan, peneliti tertarik meneliti kecenderungan topik dan jenis penelitian yang dilakukan mahasiswa angkatan 2010-2014 Prodi Pendidikan Bahasa Mandarin Unesa. Skripsi mahasiswa angkatan 2010-2014 dijadikan sebagai sumber data didasari oleh (1) mahasiswa angkatan pertama pada prodi tersebut adalah angkatan 2010 dan (2) skripsi yang telah diuji dan dinyatakan lulus dikerjakan oleh mahasiswa angkatan 2010-2014. Mahasiswa angkatan 2015 hingga saat penelitian ini dikerjakan (2019), belum ada satu pun yang telah menyelesaikan skripsinya.

Tujuan pembahasan dalam tulisan ini adalah mendeskripsikan (1) topik penelitian yang diteliti mahasiwa Prodi PBM Unesa angkatan 2010-2014; (2) jenis penelitian yang diterapkan oleh mahasiwa Prodi PBM Unesa angkatan 2010-2014; (3) kecenderungan topik dan jenis penelitian mahasiwa Prodi PBM Unesa angkatan 2010-2014.

\section{B. METODE PENELITIAN}

Penelitian ini merupakan penelitian deskriptif, karena tujuan yang hendak dicapai adalah mendeskripsikan topik, jenis penelitian, dan kecenderungan topik dan jenis penelitian mahasiwa Prodi S-1 PBM Unesa. Sumber data berupa skripsi yang ditulis oleh mahasiswa Prodi S-1 PBM Unesa angkatan 2010-2014. Data berupa topik-topik yang diteliti dan jenis penelitian yang diterapkan dalam skripsi para mahasiswa. Data dikumpulkan dengan teknik dokumentasi, teknik observasi, dan teknik catat. Teknik analisis data yang digunakan adalah teknik deskriptif kualitatif dan teknik persentase dengan rumus:

$$
\mathrm{P}=\frac{\text { skor total }}{\text { skor kriterium }} \times 100 \%
$$

\section{KAJIAN PUSTAKA}

Karya ilmiah merupakan satu jenis karya yang ditulis berdasarkan prosedur ilmiah. Untuk menghasilkan karya ilmiah, termasuk penulisan skripsi, terdapat tahap prapenulisan, tahap penulisan, dan tahap pascapenulisan (Akhadiah, dkk., 2000). Dalam tahap prapenulisan, penulis melakukan (1) pemilihan dan pembatasan topik;(2) perumusan judul; (3) perumusan tujuan penulisan;(4) pengumpulan bahan tulisan; (5) penyusunan kerangka tulisan. Secara khusus, pemilihan topik hendaknya memperhatikan kriteria (1) menarik; (2) bermanfaat; (3) dikuasai penulis; (4) dapat diteliti; (5) tersedia bahan tulisan, termasuk data penelitian.

Setelah tahap prapenulisan dilakukan, penulis melanjutkan ke tahap penulisan. Dalam tahap ini, penulis mengembangkan kerangka tulisan menjadi tulisan. Pengembangan tulisan dilakukan dengan membangun paragraf-paragraf yang kohesif dan koheren berdasarkan bahan tulisan dan data yang telah dikumpulkan penulis. Baik dalam tahap prapenulisan 
maupun penulisan, penulis melakukan tahap pascapenulisan, yakni pembacaan draf dan perevisian.

Sebagaimana telah disampaikan, skripsi merupakan salah satu jenis karya ilmiah. Dalam Buku Pedoman Akademik Unesa (2014), khususnya dalam Struktur Kurikulum Prodi Pendidikan Bahasa Mandarin, dituliskan bahwa mata kuliah Skripsi berbobot 6 SKS. Mata kuliah ini diprogram mahasiswa pada semester genap. Deskripsi mata kuliah ini berbunyi, "Penguasaan menulis karya ilmiah (skripsi) sebagai tugas akhir yang komprehensif, yang meliputi usulan penelitian, pelaksanaan penelitian, penulisan hasil penelitian, dan ujian hasil penelitian (skripsi)". Dalam deskripsi tersebut dijelaskan bahwa penulisan skripsi meliputi tahapan usulan, pelaksanaan, penulisan hasil, dan ujian hasil penelitian berupa skripsi. Dengan demikian, tidak disebutkan topik dan jenis penelitian skripsi yang hendaknya diambil mahasiswa pemrogram mata kuliah tersebut. Dengan demikian, mahasiswa Prodi S-1 PBM Unesa, dengan didampingi oleh dosen pembimbing skripsi (DPS) berhak memilih topik penelitian dan jenis penelitian yang akan dikerjakannya.

Pada Prodi Pendidikan Bahasa Mandarin Unesa untuk angkatan 2010-2014, mahasiswa menempuh mata kuliah Metodologi Penelitian Pendidikan (4 SKS) dan mata kuliah Metodologi Penelitian Bahasa dan Sastra (3 SKS). Kedua mata kuliah tersebut bersifat wajib tempuh. Namun, dalam Kurikulum Berbasis KKNI untuk angkatan 2015 dan seterusnya terjadi perubahan, yakni mata kuliah Metodologi Penelitian Pendidikan (3 SKS) bersifat wajib dan mata kuliah Metodologi Penelitian Bahasa dan Sastra (3 SKS) bersifat pilihan.

Dalam mata kuliah Metodologi Penelitian Pendidikan, para mahasiswa mempelajari (1) Hakikat dan Fungsi Penelitian; (2) Perumusan Masalah dan Judul Penelitian; (3) Perumusan Tujuan dan Manfaat Penelitian; (4) Variabel dan Hipotesis Penelitian; (5) Kajian Pustaka yang Relevan; (6) Aneka Jenis Penelitian Pendidikan; (7) Metode Penelitian; (8) Penyusunan Proposal Penelitian. Utamanya dalam materi ke-6, mereka mempelajari jenis-jenis penelitian pendidikan, yakni penelitian deskriptif, penelitian korelasional, penelitian eksperimen, penelitian pengembangan, dan penelitian tindakan kelas. Sejumlah materi dalam mata kuliah tersebut membekali para mahasiswa untuk menyusun proposal penelitian pendidikan (Buku Pedoman Akademik Unesa, 2014).

Penelitian deskriptif merupakan penelitian yang dirancang untuk memperoleh informasi tentang status gejala saat penelitian dilakukan; tidak ada perlakuan; bertujuan mendeskripsikan variabel atau kondisi "apa yang ada" dalam suatu situasi; lazimnya tidak diarahkan untuk menguji hipotesis (Arikunto, 2003). Penelitian eksperimen merupakan kegiatan yang direncanakan dan dilaksanakan peneliti untuk mengumpulkan bukti-bukti yang ada hubungannya dengan hipotesis; dirancang untuk menguji hipotesis; bercirikan (1) suatu variabel bebas (VB) dimanipulasi; (2) variabel terikat (VT) dipertahankan tetap; (3) pengaruh manipulasi VB terhadap VT diamati (Sugiyono, 2011). Selanjutnya, penelitian pengembangan merupakan (1) suatu proses mengembangkan dan memvalidasi "produk pendidikan"; (2) produk pendidikan bisa berupa materi ajar, instrumen evaluasi, atau model pembelajaran untuk mengatasi masalah dalam pembelajaran (di kelas, laboratorium, atau di luar kelas); (3) cakupan penelitian pengembangan adalah studi pendahuluan tentang produk yang akan dikembangkan dan situasi lapangan; (4) pengembangan produk atas dasar hasil studi pendahuluan; uji lapangan produk yang sudah dikembangkan; penyempurnaan produk berdasarkan hasil uji lapangan; (5) merupakan upaya menghasilkan produk yang siap digunakan secara nyata di lapangan (Sugiyono, 2011). Selanjutnya, penelitian tindakan kelas (PTK) merupakan penelitian yang dilakukan guru guna memperbaiki atau meningkatkan kualitas pendidikan di kelas tertentu. PTK dilaksanakan minimal dalam dua siklus. Dalam tiap 
siklus terdapat tahapan perencanaan, pengimplementasian tindakan, observasi dan evaluasi, dan refleksi (Susanto, 2008).

\section{PEMBAHASAN}

Dalam bagian ini disampaikan hasil penelitian guna menjawab masalah penelitian sebagaimana yang disuratkan dalam tujuan tulisan ini. Hal-hal yang disajikan meliputi (1) topik penelitian; (2) jenis penelitian; (3) kecenderungan topik dan jenis penelitian mahasiswa Angkatan 2010-2014 Prodi S-1 PBM Unesa.

\section{Topik Penelitian Skripsi Mahasiswa Angkatan 2010-2014 Prodi S-1 Pendidikan Bahasa Mandarin Universitas Negeri Surabaya}

Berdasarkan sumber data yang digunakan dalam penelitian ini, hasil penelitian tentang topik-topik penelitian lima angkatan (2010, 2011, 2012, 2013, 2014) mahasiswa Prodi Pendidikan Bahasa Mandarin Unesa adalah (1) pembelajaran bahasa Mandarin, (2) kebahasaan, dan (3) kesusastraan atau kebudayaan Tiongkok. Secara rinci, topik-topik penelitian tersebut disajikan secara lengkap berikut ini.

Mahasiswa Prodi S-1 PBM FBS Unesa 2010 merupakan mahasiswa angkatan pertama, karena ini prodi ini didirikan dan dibuka pada 2010. Jumlah mahasiswa angkatan ini sebanyak 13 orang. Dari 13 mahasiswa tersebut, skripsi yang ditulis berjenis penelitian pendidikan sebanyak 2 orang dan sebanyak 11 orang melakukan penelitian deskriptifkualitatif. Dari dua orang yang meneliti pembelajaran, satu orang melaksanakan penelitian pengembangan bahan ajar dan satu orang melakukan penelitian eksperimen. Bahan ajar yang dikembangkan berupa buku saku sebagai suplemen materi pembelajaran bahasa Mandarin untuk tingkat pemula SMA/SMK. Berikutnya, satu orang meneliti pengaruh penggunaan media komputer terhadap kemampuan menulis hanzi. Selanjutnya, dari sebelas orang yang memilih penelitian deskriptif-kualitatif terdapat 7 penelitian tentang analisis kesalahan berbahasa, khususnya penelitian kesalahan penggunaan kata; 2 penelitian tentang stilistika, khususnya tentang gaya bahasa dalam album lagu berbahasa Mandarin dan gaya bahasa dalam kumpulan puisi. Sebanyak satu penelitian membahas budaya, yakni persepsi masyarakat terhadap simbol naga, serta satu penelitian tentang apresiasi unsur intrinsik (tema) dalam novel. Perhatikan tabel 1 berikut ini.

Tabel 1. Topik Penelitian Mahasiswa Prodi S-1 PBM Unesa Angkatan 2010

\begin{tabular}{|c|l|c|c|}
\hline Angkatan & \multicolumn{1}{|c|}{ Topik Penelitian } & Jumlah & Persentase \\
\hline \multirow{4}{*}{2010} & Media pembelajaran & 1 & $7,69 \%$ \\
\cline { 2 - 4 } & Bahan ajar & 1 & $7,69 \%$ \\
\cline { 2 - 4 } & Analisis kesalahan berbahasa & 7 & $53,85 \%$ \\
\cline { 2 - 4 } & Stilistika & 2 & $15,38 \%$ \\
\cline { 2 - 4 } & Budaya Tiongkok dan Indonesia & 1 & $7,69 \%$ \\
\cline { 2 - 4 } & Apresiasi karya sastra Tiongkok & $\mathbf{7 , 6 9 \%}$ \\
\hline \multicolumn{2}{|c|}{ Total } & $\mathbf{1 3}$ & $\mathbf{1 0 0 \%}$ \\
\hline
\end{tabular}

Berikutnya, topik penelitian mahasiswa Angkatan 2011 Prodi Pendidikan Bahasa Mandarin Unesa. Dari 56 mhasiswa angkatan 2011, yang meneliti topik pembelajaran sebanyak 20 mahasiswa dengan rincian sebanyak 9 orang meneliti penggunaan media dalam pembelajaran bahasa Mandarin, sebanyak 7 orang meneliti penerapanan metode dalam pembelajaran bahasa Mandarin, dan sebanyak 3 orang meneliti pengembangan 
bahan ajar serta 1 orang meneliti pengembangan media pembelajaran. Berikutnya, mahasiswa meneliti topik-topik yang sesuai dengan analisis kesalahan berbahasa sebanyak 12 orang, sebanyak 5 orang meneliti bidang pragmatik; sebanyak 5 orang meneliti topik dalam sosiolinguistik, sebanyak 5 orang meneliti topik tentang apresiasi karya sastra, sebanyak 6 orang meneliti stilistika, sebanyak 5 orang meneliti topik stilistika sebanyak 6 orang, psikologi sastra, dan 1 orang meneliti folklor.

Topik-topik yang diteliti mahasiswa angkatan 2011 tersebut disajikan dalam tabel sebagai berikut.

Tabel 2. Topik Penelitian Mahasiswa Prodi S-1 PBM Unesa Angkatan 2011

\begin{tabular}{|l|l|l|l|}
\hline Angkatan & \multicolumn{1}{|c|}{ Topik Penelitian } & Jumlah & \multicolumn{1}{|c|}{ Persentase } \\
\hline \multirow{5}{*}{2011} & Metode pembelajaran & 7 & $12,5 \%$ \\
\cline { 2 - 4 } & Media pembelajaran & 10 & $17,86 \%$ \\
\cline { 2 - 4 } & Bahan ajar & 3 & $5,36 \%$ \\
\cline { 2 - 4 } & Analisis kesalahan berbahasa & 12 & $21,43 \%$ \\
\cline { 2 - 4 } & Pragmatik & 5 & $8,9 \%$ \\
\cline { 2 - 4 } & Sosiolinguistik & 5 & $8,9 \%$ \\
\cline { 2 - 4 } & Stilistika & 6 & $10,7 \%$ \\
\cline { 2 - 4 } & Apresiasi karya sastra Tiongkok & 5 & $8,9 \%$ \\
\cline { 2 - 4 } & Psikologi sastra & 3 & $5,36 \%$ \\
\cline { 2 - 4 } & Folklor & 1 & 1,8 \\
\hline & Total & $\mathbf{5 6}$ & $\mathbf{1 0 0} \%$ \\
\hline
\end{tabular}

Topik-topik penelitian mahasiswa angkatan 2012 adalah sebagai berikut. Jumlah penelitian yang dilakukan oleh mahasiswa angkatan 2012 sebanyak 67 dengan rincian sebanyak 43 penelitian bertopikkan pembelajaran bahasa Mandarin, sebanyak 11 penelitian tentang bahasa Mandarin, dan sebanyak 13 penelitian tentang kesusastraan. Secara lebih rinci, penelitian pembelajaran bahasa Mandarin sebanyak 11 penelitian tentang pengggunaan metode, sebanyak 24 tentang penggunaan media, dan sebanyak 1 penelitian tentang penggunaan bahan ajar. Selanjutnya, sebanyak 4 penelitian tentang pengembangan media pembelajaran bahasa Mandarin dan sebanyak satu penelitian tentang keterampilan berbahasa Mandarin, yakni keterampilan menulis. Berikutnya, penelitian kebahasaan terdiri atas penelitian tentang analisis kontrastif sebanyak satu judul, analisis kesalahan berbahasa sebanyak lima judul, pragmatik empat judul, dan satu judul bertopikkan kajian sosiolinguistik. Penelitian bertopikkan kesusastraan terdiri atas penelitian psikologi sastra sebanyak tujuh judul, tentang sosiologi sastra sebanyak empat judul, dan tentang stilistika sebanyak dua judul.

Topik-topik yang diteliti mahasiswa angkatan 2012 tersebut disajikan dalam tabel sebagai berikut.

Tabel 3. Topik Penelitian Mahasiswa Prodi S-1 PBM Unesa Angkatan 2012

\begin{tabular}{|c|l|l|l|}
\hline Angkatan & \multicolumn{1}{|c|}{ Topik Penelitian } & Jumlah & \multicolumn{1}{|c|}{ Persentase } \\
\hline \multirow{4}{*}{2012} & Metode pembelajaran & 11 & $16,4 \%$ \\
\cline { 2 - 4 } & Media pembelajaran & 28 & $41,79 \%$ \\
\cline { 2 - 4 } & Bahan ajar & 1 & $1,49 \%$ \\
\cline { 2 - 4 } & Keterampilan berbahasa & 1 & $1,49 \%$ \\
\cline { 2 - 4 } & Analisis kontrastif & 1 & $1,49 \%$ \\
\cline { 2 - 4 } & Analisis kesalahan berbahasa & 5 & $7,46 \%$ \\
\hline
\end{tabular}




\begin{tabular}{|c|l|l|l|}
\hline \multirow{4}{*}{} & Pragmatik & 4 & $5,97 \%$ \\
\cline { 2 - 4 } & Sosiolinguistik & 1 & $2,98 \%$ \\
\cline { 2 - 4 } & Stilistika & 2 & $2,98 \%$ \\
\cline { 2 - 4 } & Apresiasi karya sastra Tiongkok & 5 & $7,46 \%$ \\
\cline { 2 - 4 } & Sosiologi sastra & 4 & $5,97 \%$ \\
\cline { 2 - 4 } & Psikologi sastra & 7 & $10,48 \%$ \\
\hline \multicolumn{2}{|r|}{ Total } & 67 & $100 \%$ \\
\hline
\end{tabular}

Topik-topik penelitian yang diteliti mahasiswa angkatan 2013 Prodi Pendidikan Bahasa Mandarin Unesa adalah sebagai berikut. Total penelitian yang telah ditulis mahasiswa angkatan 2013 sebanyak 56 judul dengan rincian sebanyak 31 judul bertopikkan pembelajaran; penelitian bertopikkan kebahasaan sebanyak 16 judul, sedang penelitian bertopikkan kesastraan sebanyak 10 judul penelitian. Secara lebih rinci, mahasiswa yang meneliti topik tentang media pembejaran sebanyak 22 judul; metode pembelajaran sebanyak 6 judul; bahan ajar sebanyak 2 judul. Berikutnya, topik penelitian tentang kebahasaan meliputi (1) sintaksis sebanyak 2 judul, (2) semantik sebanyak 1 judul, (3) sintaksis sebanyak 2 judul, (4) penerjemahan sebanyak 1 judul, (5) analisis kesalahan berbahasa sebanyak 8 judul, pragmatik sebanyak 3 judul, dan sosiolinguistik sebanyak 1 judul. Topik penelitian tentang sastra meliputi (1) psikologi sastra sebanyak 3 judul, (2) stilistika sebanyak 3 judul, dan (3) sosiologi sastra sebanyak 3 judul.

Tabel 4. Topik Penelitian Mahasiswa Prodi S-1 PBM Unesa Angkatan 2013

\begin{tabular}{|l|l|l|l|}
\hline Angkatan & \multicolumn{1}{|c|}{ Topik Penelitian } & Jumlah & Persentase \\
\hline \multirow{5}{*}{2013} & Metode pembelajaran & 6 & $10,71 \%$ \\
\cline { 2 - 4 } & Media pembelajaran & 22 & $39,28 \%$ \\
\cline { 2 - 5 } & Bahan ajar & 2 & $3,57 \%$ \\
\cline { 2 - 5 } & Analisis kesalahan berbahasa & 8 & $14,28 \%$ \\
\cline { 2 - 5 } & Linguistik & 3 & $5,35 \%$ \\
\cline { 2 - 5 } & Penerjemahan & 1 & $1,78 \%$ \\
\cline { 2 - 5 } & Pragmatik & 3 & $5,35 \%$ \\
\cline { 2 - 5 } & Sosiolinguistik & 1 & $1,78 \%$ \\
\cline { 2 - 5 } & Stilistika & 3 & $5,35 \%$ \\
\cline { 2 - 5 } & Sosiologi sastra & 3 & $\mathbf{3}, 1 \%$ \\
\cline { 2 - 5 } & Psikologi sastra & $\mathbf{5 6}$ & $\mathbf{1 0 0 \%}$ \\
\hline
\end{tabular}

Topik-topik penelitian mahasiswa angkatan 2014 terdiri atas penelitian pembelajaran sebanyak 35 judul, kebahasaan sebanyak 14 judul, kesastraan sebanyak 7 judul. Rincian topik-topik pembelajaran terdiri atas metode pembelajaran (12 judul); media pembelajaran (20 judul); bahan ajar ( 3 judul). Topik-topik penelitian tentang kebahasaan terdiri atas analisis kesalahan berbahasa ( 8 judul), pragmatik (4 judul), analisis wacana ( 2 judul). Penelitian bertopik sastra sebanyak 7 judul dengan rincian: psikologi sastra (3 judul), apresiasi sastra ( 1 judul), dan stilistika ( 3 judul). Topik yang paling sedikit diteliti adalah penerjemahan $(1,78 \%)$ dan sosiolinguistik $(1,78 \%)$. 
Tabel 5. Topik Penelitian Mahasiswa Prodi S-1 PBM Unesa Angkatan 2014

\begin{tabular}{|l|l|l|l|}
\hline Angkatan & \multicolumn{1}{|c|}{ Topik Penelitian } & Jumlah & Persentase \\
\hline \multirow{4}{*}{2014} & Metode pembelajaran & 12 & $21,8 \%$ \\
\cline { 2 - 4 } & Media pembelajaran & 20 & $36,36 \%$ \\
\cline { 2 - 4 } & Bahan ajar & 3 & $5,45 \%$ \\
\cline { 2 - 4 } & Analisis kesalahan berbahasa & 8 & $14,54 \%$ \\
\cline { 2 - 4 } & Pragmatik & 4 & $7,27 \%$ \\
\cline { 2 - 4 } & Analisis wacana & 2 & $3,6 \%$ \\
\cline { 2 - 4 } & Stilistika & 3 & $5,45 \%$ \\
\cline { 2 - 4 } & Apresiasi karya sastra Tiongkok & 1 & $1,8 \%$ \\
\cline { 2 - 4 } & Psikologi sastra & 3 & $5,45 \%$ \\
\hline \multicolumn{2}{|c|}{ Total } & $\mathbf{5 5}$ & $\mathbf{1 0 0 \%}$ \\
\hline
\end{tabular}

\section{Jenis Penelitian Mahasiswa Angkatan 2010-2014 Prodi PBM Unesa}

Dalam subjudul ini disampaikan hasil penelitian tentang jenis penelitian yang dipilih dan dilakukan mahasiswa angkatan 2010-2014 Prodi PBM Unesa. Jenis penelitian per angkatan disampaikan berikut ini.

Mahasiswa Angkatan 2010 Prodi S-1 Pendidikan Bahasa Mandarin Unesa yang telah lulus sebanyak 13 orang. Jenis penelitian yang dipilih dan dilaksanakan adalah (1) eksperimen (1 orang), (2) penelitian dan pengembangan (1 orang), (3) deskriptif kualitatif (11 orang). Hasil perhitungan dengan rumus persentase tiap jenis penelitian disajikan dalam tabel berikut ini.

Tabel 6. Jenis Penelitian Mahasiswa Prodi S-1 PBM Unesa Angkatan 2010

\begin{tabular}{|c|c|l|l|c|}
\hline Angkatan & \multicolumn{2}{|c|}{ Jenis Penelitian } & Jumlah & Persentase \\
\hline \multirow{3}{*}{2010} & \multirow{2}{*}{ Pendidikan } & Eksperimen & 1 & $7,7 \%$ \\
\cline { 2 - 5 } & penelitian dan pengembangan & 1 & $7,7 \%$ \\
\cline { 2 - 5 } & Deskriptif-kualitatif & 11 & $84,60 \%$ \\
\hline \multicolumn{2}{|r|}{ Total } & $\mathbf{1 3}$ & $\mathbf{1 0 0 \%}$ \\
\hline
\end{tabular}

Mahasiswa Angkatan 2011 sebanyak 56 orang. Jenis penelitan yang mereka pilih untuk skripsi adalah (1) penelitian eksperimen (16 judul), (2) penelitian dan pengembangan (4 judul), (3) penelitian deskriptitif-kualitatif (36 judul). Hasil perhitungan dengan rumus persentase tiap jenis penelitian disajikan dalam tabel berikut ini.

Tabel 7. Jenis Penelitian Mahasiswa Prodi S-1 PBM Unesa Angkatan 2011

\begin{tabular}{|c|c|c|c|c|}
\hline Angkatan & \multicolumn{2}{|r|}{ Jenis Penelitian } & Jumlah & Persentase \\
\hline \multirow{3}{*}{2011} & \multirow{2}{*}{ Pendidikan } & Eksperimen & 16 & $28,57 \%$ \\
\hline & & penelitian dan pengembangan & 4 & $7,1 \%$ \\
\hline & \multicolumn{2}{|r|}{ Deskriptif-kualitatif } & 36 & \\
\hline & & Total & 56 & $100 \%$ \\
\hline
\end{tabular}

Jenis penelitian yang dipilih dan digunakan oleh mahasiswa angkatan 2012 Prodi Pendidikan Bahasa Mandarin Unesa dijelaskan sebagai berikut. Sebanyak 67 mahasiswa telah menyelesaikan skripsi mereka. Rincian jenis penelitian yang digunakan adalah sebagai berikut. 
Tabel 8. Jenis Penelitian Mahasiswa Prodi S-1 PBM Unesa Angkatan 2012

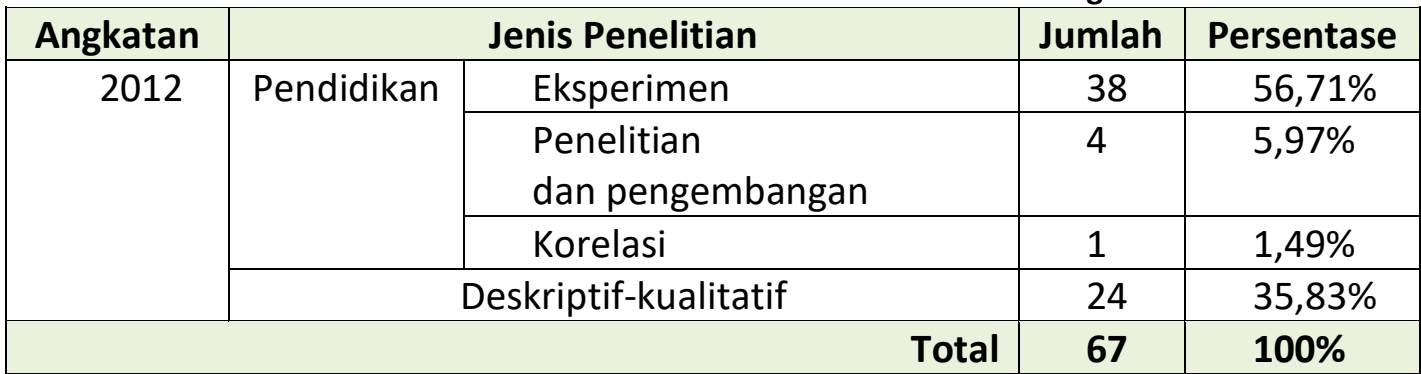

Selanjutnya, mahasiswa S-1 Prodi Pendidikan Bahasa Mandarin Unesa Angkatan 2013. Sebanyak 56 mahasiswa telah menyelesaikan skripsi. Adapun jenis-jenis penelitian yang mereka gunakan adalah sebagai berikut.

Tabel 9. Jenis Penelitian Mahasiswa Prodi S-1 PBM Unesa Angkatan 2013

\begin{tabular}{|c|c|c|c|c|}
\hline Angkatan & \multicolumn{2}{|c|}{ Jenis Penelitian } & Jumlah & Persentase \\
\hline \multirow{4}{*}{2013} & \multirow{3}{*}{ Pendidikan } & Eksperimen & 25 & $44,64 \%$ \\
\hline & & $\begin{array}{l}\text { Penelitian } \\
\text { dan pengembangan }\end{array}$ & 6 & $10,07 \%$ \\
\hline & & Korelasi & 1 & $1,79 \%$ \\
\hline & \multicolumn{2}{|c|}{ Deskriptif-kualitatif } & 24 & $42,86 \%$ \\
\hline & & Total & 56 & $100 \%$ \\
\hline
\end{tabular}

Selanjutnya, pilihan jenis penelitian oleh mahasiswa S-1 Prodi Pendidikan Bahasa Mandarin Unesa Angkatan 2014 adalah sebagai berikut. Sebanyak 55 mahasiswa telah menyelesaikan skripsi. Sebanyak 35 mahasiswa memilih penelitian pendidikan, sedangkan sebanyak 21 orang memilih penelitian deksriptif-kualitatif. Secara rinci, jenis penelitian yang mereka pilih disajikan dalam tabel berikut ini.

Tabel 10. Jenis Penelitian Mahasiswa Prodi S-1 PBM Unesa Angkatan 2014

\begin{tabular}{|l|l|l|l|l|}
\hline Angkatan & \multicolumn{2}{|c|}{ Jenis Penelitian } & Jumlah & Persentase \\
\hline \multirow{3}{*}{2014} & \multirow{2}{*}{ Pendidikan } & Eksperimen & 31 & $56,36 \%$ \\
\cline { 3 - 5 } & & Penelitian dan pengembangan & 3 & $5,45 \%$ \\
\cline { 2 - 4 } & & Korelasi & 1 & $1,81 \%$ \\
\cline { 2 - 4 } & \multicolumn{2}{|c|}{ Deskriptif-kualitatif } & 21 & $38,18 \%$ \\
\hline & \multicolumn{2}{|c|}{ Total } & $\mathbf{1 0 0 \%}$ \\
\hline
\end{tabular}

3. Kecenderungan Topik dan Jenis Penelitian Mahasiswa Angkatan 2010-2014 Prodi PBM Unesa

Berdasarkan pemaparan pada subjudul 1 dan subjudul 2, disajikan kecenderungan topik dan jenis penelitian oleh mahasiswa angkatan 2010-2014 Prodi PBM Unesa sebagai berikut.

Kecenderungan topik penelitian oleh mahasiswa angkatan 2010 kadalah kebahasaan, khususnya kesalahan berbahasa, sedangkan jenis penelitian deskriptif-kualitatif. Angkatan 2011 berkecenderungan meneliti topik kebahasaan dan kesusastraan. Ini dibuktikan dengan penelitian kebahasaan (kesalahan berbahasa) dan kesusastraan (stilistika, pragmatik, dan apresisasi karya sastra). Karena itu, kecenderungan jenis penelitiannya adalah deskriptifkualitatif. 
Kedua kecenderungan topik penelitian dan jenis penelitian oleh mahasiswa angkatan 2010 dan 2011 tersebut bergeser pada mahasiswa angkatan 2012. Pada angkatan ini, topiktopik penelitian yang mendominasi adalah pembelajaran bahasa, khususnya penggunaan aneka media pembelajaran. Meski demikian, kecenderungan meneliti kebahasaan dan kesastraan masih hampir seimbang dengan penelitian pendidikan. Hal ini dibuktikan dengan topik penelitian kebahasaan sebanyak 11 judul dan penelitian kesastraan sebanyak 13 judul. Berdasarkan kecenderungan topik-topik penelitian tersebut, kecenderungan jenis penelitian angkatan 2012 adalah jenis penelitian eksperimen dan penelitian deskriptif-kualitatif.

Kecenderungan yang sama dengan angkatan 2012 adalah angkatan 2013. Mereka lebih cenderung meneliti topik-topik pembelajaran, yakni penggunaan media dan metode pembelajaran. Adapun penelitian kebahasaan masih cenderung ke topik penelitian tentang kesalahan berbahasa. Mengingat kecenderungan pilihan topik yang seperti itu, kecenderungan jenis penelitian adalah penelitian eksperimen dan penelitian deskritifkualitatif.

Kecenderungan topik dan jenis penelitian sebagaimana dilakukan mahasiswa angkatan 2013 juga terjadi pada angkatan 2014. Topik-topik yang diteliti berkecenderungan ke pembelajaran bahasa Mandarin, utamanya penggunaan media (23 judul) dan metode pembelajaran(6 judul). Kecenderungan kedua adalah ke topik-topik penelitian kebahasaan (13 judul) dan kesastraan (10 judul). Berdasarkan dua kecenderungan topik tersebut, kecenderungan jenis penelitian oleh mahasiswa Angkatan 2013 adalah penelitian eksperimen dan penelitian deskriptif -kualitatif.

Kecenderungan topik dan jenis penelitian angkatan 2013 juga terjadi pada mahasiswa angkatan 2014. Topik-topik penelitian mereka berkecenderungan ke penggunaan media (19 judul) dan metode pembelajaran (12 judul). Kecenderungan ke penelitian kebahasaan sebanyak 14 judul dan kesastraan sebanyak 7 judul. Kemudian, sejalan dengan kecenderunagn pilihan topik penelitian, jenis penelitan eksperimen (judul 31 judul) dan penelitian deskriptif-kualitatif sebanyak 21 judul merupakan kecenderungan penelitian angkatan 2014.

\section{E. SIMPULAN}

Berdasarkan sajian hasil analisis data dan pembahasan dapat disimpulkan sebagai berikut.

1. Topik-topik yang diteliti oleh mahasiswa angkatan 2010, 2011, 2012, 2013, dan 2014 adalah (1) pendidikan, (2) kebahasaan, dan (kesastraan). Topik pendidikan meliputi (1) penggunaan media dalam pembelajaran bahasa Mandarin, (2) penggunaan metode dalam pembelajaran bahasa Mandarin, (3) pengembangan bahan ajar. Topik kebahasaan mencakup (1) kesalahan berbahasa, (2) pragmatik, (3) sosiolinguistik, (4) keterampilan berbahasa. Topik kesastraan meliputi (1) stilistika, (2) psikologi sastra, dan (3) apresiasi karya sastra.

2. Jenis-jenis penelitian yang dipilih dan digunakan oleh mahasiswa angkatan 2010-2014 Prodi S-1 PBM Unesa meliputi penelitian pendidikan dan penelitian non-pendidikan. Penelitian pendidikan yang dipilih meliputi (1) penelitian eksperimen, (2) penelitian dan pengembangan, dan (3) penelitian korelasi. Adapun penelitian non-pendidikan yang dipilih dan digunakan oleh mahasiswa angkatan 2010-2014 adalah penelitian deskriptif-kualitatif, baik untuk penelitian di bidang kebahasaan maupun kesastraaan.

3. Kecenderungan pemilihan topik penelitian dan jenis penelitian berjalan seiring. Dalam hal ini, pilihan topik pembelajaran bahasa Mandarin didominasi oleh topik penelitian penggunaan media dan metode pembelajaran bahasa Mandarin dan jenis penelitian yang 
digunakan adalah penelitian eksperimen. Berikutnya, topik kebahasaan yang banyak dipilih untuk diteliti adalah penelitian tentang kesalahan berbahasa Mandarin dan pragmatik, sedangkan topik penelitian tentang kesastraan yang banyak dipilh adalah penelitian stilistika dan psikologi sastra. Pilihan kedua topik tersebut sejalan dengan jenis penelitian yang mendominasi untuk digunakan yaitu penelitian deskriptif-kualitatif.

\section{DAFTAR PUSTAKA}

[1] Akhadiah, Sabarti, dkk. 2000. Pembinaan Kemampuan Menulis Bahasa Indonesia. Jakarta: Erlangga.

[2] Arikunto, Suharsimi. 2003. Manajemen Penelitian Pendidikan.Jakarta: P2LPTK.

[3] Buku Pedoman Akademik Universitas Negeri Surabaya 2014/2015. Surabaya: Unesa Press.

[4] Permenristekdikti nomor 44 Tahun 2015 tentang Standar Nasional Pendidikan Tinggi.Jakarta: Kemenristekdikti.

[5] Sugiyono. 2011. Metodologi Penelitian Pendidikan. Bandung: Alfabet.

[6] Susanto. 2008. Penelitian Tindakan Kelas. Surabaya: Unesa University Press.

\section{DATA PENULIS}

$\begin{array}{ll}\text { Nama }^{1} & \text { : Dr. Maria Mintowati, M.Pd. } \\ \text { Prodi } & : \text { Pendidikan Bahasa Mandarin } \\ \text { Perguruan Tinggi } & : \text { Universitas Negeri Surabaya } \\ \text { Telp } & : \text { O81357127015 } \\ \text { Email } & \text { mintowati@unesa.ac.id } \\ & \text { : Dr. Tengsoe Tjahjono, M.Pd. } \\ \text { Nama }{ }^{2} & : \text { Pendidikan Bahasa Mandarin } \\ \text { Program Studi } & \text { : Universitas Negeri Surabaya } \\ \text { Perguruan Tinggi } & \text { : tengsoetjahjono@unesa.ac.id } \\ \text { Email } & \text { : Hans Yosef Tandra Dasion, B.Ed., M.TSOL } \\ \text { Nama } & \text { : Pendidikan Bahasa Mandarin } \\ \text { Program Studi } & : \text { Universitas Negeri Surabaya } \\ \text { Perguruan Tinggi } & \text { : hansdasion@unesa.ac.id } \\ \text { Email } & \end{array}$

